\title{
Towards sustainable consumption in Albania
}

\section{Anita GUMENI; Ornela SHALARI; Pranvera MULLA}

\author{
University of Tirana, Faculty of Economics, Saranda Branch, Albania \\ e-mail correspondence: ornela.shalari@unitir.edu.al
}

\begin{abstract}
In recent years, there has been an increasing awareness towards economic, environmental, and social problems of the actual development system. However, sustainable development remains one of the main challenges of actual times. Sustainable consumption plays a significant role in achieving sustainable development goals. Moving towards more sustainable patterns of consumption will reduce environmental damage, adjust social inequalities, and increase economic efficiency. Therefore, it is substantial to investigate the determinants of sustainable consumption behaviour. The aim of this paper is to identify whether the Albanian consumers adopt sustainable consumption behaviour. An empirical analysis is used to identify the main factors that influence sustainable consumption of Albanian consumers. The results have revealed that sustainable consumption in Albania is a niche segment. The main determinants of sustainable consumption behaviour in Albania are: internal factors such as personality characteristic's, Perceived Consumer Effectiveness, knowledge, and attitudes towards sustainable consumption, and external factors.
\end{abstract}

Keywords: sustainable development, sustainable consumption, consumers behaviour JEL classification: E21, D12, D14

\section{INTRODUCTION}

The main economic problem is caused because the natural resources are limited and the human demands unlimited.The actual patterns of consumption are unsustainable and are draining the natural resources. Consequently, there is a growing need to change towards more sustainable patterns of consumption (Baumol \& Oates, 1998).

As is pointed out in agenda 21 (4.3) "... The major cause of the continued deterioration of the global environment is the unsustainable pattern of consumption and production, particularly in industrialized countries, which is a matter of grave concern, aggravating poverty and imbalances." The aim of sustainable consumption and production (SCP) is to "produce more and better with less" ( UNEP, 2012). Additionally, sustainable consumption can be used as a vital instrument in reducing social inequality (Zoysa, 2011; UN, 2015). SCP integrates the social, economic, and environmental dimension of sustainability (UN, 2015).

The Oslo Symposium gives the first definition of sustainable consumption and production: "The use of goods and services that respond to basic needs and bring a better quality of life, while minimizing the use of natural resources, toxic materials and emissions of waste and pollutants over the life cycle, so as not to jeopardize the needs of future generations." (Oslo 1994).

The progress towards sustainability has been very slow, particularly in developing countries. SCP cannot be achieved only by changes in one level and one direction). Sustainable development requires efforts at all levels (local, regional, global 
level) by all the stakeholders of society (individuals, governments, companies, and NGOs). (UN, 2015).

There are two main alternative discourses on sustainable consumption: the week approach of sustainable consumption (wSC) and the strong approach of sustainable consumption (sSC) (Lorek \& Fuchs, 2011; Young, Hwang, McDonald, \& Oats, 2010). According to the (wSC) sustainable development can be achieved only through technological advancement (Lorek \& Fuchs, 2011; Young, Hwang, McDonald, \& Oats, 2010). On the other hand (sCS) assumes that in order to achieve sustainable development we should change the levels and the models of consumption. Individuals have a vital role in achieving sustainable consumption not only as consumers but as citizens also. (Lorek \& Fuchs, 2011). The consumer behaviour has a direct impact on the environment, personal wellbeing, and total welfare (Spaagaren, 2003). Consumers influence the offer through purchasing power. They can boycott products that harm the environment and support sustainable products (Jackson, 2005; Luchs, Naylor, Irwin, \& Raghunathan, 2010). Their pressure can oblige companies to adapt sustainable production patterns (ECEU, 2011) (WBCSD). On the other hand, consumers can support and vote policies that promote sustainable consumption and production (ECEU, 2011) (WBCSD).

Because of the significant role that individuals play in achieving sustainable consumption, as consumers and as citizens, it is significant to investigate their attitude and behaviour toward sustainable consumption. Despite the enlarged awareness on sustainable consumption, SC remains a niche segment. Therefore, there is necessary to analyse consumer behaviour-attitude gap towards sustainable consumption (Power \& Mont, 2010). Numerous academic researchers have been conducted in order to analyse the determinants that influence consumer behaviour toward sustainable consumption (Diamandopoulos, 2003; Ehrich \& Irwin, 2005) (Vermier \& Verebeke, 2006; Thøgersen, 2010; Pezzini, 2013; Von Meyer-Höfer, Wense, \& Spiller, 2013; Anastasiadis \& Dam, 2014). Most of the researches on sustainable consumption have been undertaken for developed countries. On the other hand, there are only few studies on sustainable consumption in developing countries. However, sustainable patterns vary a lot between developed and emerging countries. Data have shown that if the unsustainable models of consumption change towards more sustainable models of consumption in the early stages of development there will be less irreversible damage in the specific county. Consequently, orientation towards sustainable consumer behaviour should be a priority for the developing countries also.

The purpose of this paper is to examine Albanian consumers actions towards sustainable consumption. Empirical research is used to identify the main factors that influence consumer behaviour toward sustainable consumption.

Several authors have revealed that there are two main factors that influence the decision making process towards sustainable consumption: Internal factors (psychographic characteristics, demographic) and external factors (macro and micro environment) (Vermier \& Verebeke, 2006; Chen, Lobo, \& Rajendran, 2014; Von Meyer-Höfer, Wense, \& Spiller, 2013; Anastasiadis \& Dam, 2014).

Demographic factors influence consumer attitude towards sustainable consumption (Pezzini, 2013). Empirical researches have shown that females are more prone to adapt sustainable consumption behaviour (Blend \& van Ravenswaay, 1999; Von Meyer-Höfer, Wense, \& Spiller, 2013). Income and education are positively related to sustainable consumption (Blend \& van Ravenswaay, 1999). Also, consumers worried about their health and product quality are more likely to adapt sustainable 
consumption patterns (Vermier \& Verebeke, 2006; Chen, Lobo, \& Rajendran, 2014; Von Meyer-Höfer, Wense, \& Spiller, 2013; Anastasiadis \& Dam, 2014).

Social norms have an important influence on consumer behaviour towards SC. Empirical researches have indicated that values and principles such as honesty, freedom, responsibility, equality, altruism, idealism are related to sustainable consumption patterns (Straughan \& Roberts, 1999) (Vermier \& Verebeke, 2006). Conversely, values such as ambition, hedonism, tradition are related with unsustainable consumption patterns (Vermier \& Verebeke, 2006)

Lifestyle is potentially a helpful tool to analyse progress toward sustainable consumption. Bruno and Grunert define consumption-related lifestyles as the: "system of cognitive categories, scripts, and their associations, which relate a set of products to a set of values" (Brunsø \& Grunert, 1995). Several studies have analysed the role of lifestyle in adapting sustainable consumption models (Chen, Lobo, \& Rajendran, 2014; Young, Hwang, McDonald, \& Oats, 2010).

(Anastasiadis \& Dam, 2014) specifies that concern about sustainability influence sustainable consumption. Consumers attitude towards issues such as: environmental problems, insufficiency of natural resources, sustainability, etc. motivates or demotivate sustainable consumption. Empirical evidences have pointed out a strong positive relation between attitude toward environmental issues and sustainable consumption (Straughan \& Roberts, 1999; Blend \& van Ravenswaay, 1999; Young, Hwang, McDonald, \& Oats, 2010; Papaoikonomou, Valverde, \& Ryan, 2012) If consumer believe that their actions will have an impact in achieving sustainability will be more likely to adapt sustainable consumption patterns. On the other hand, consumer who believe that their behaviour has no impact on sustainability will be less likely to adopt sustainable behaviour (Straughan \& Roberts, 1999; Von Meyer-Höfer, Wense, \& Spiller, 2013).

Consumer behaviour is shaped and influenced by external factors also. Academics have underlined different external factors that influence decision-making process:(i) the price of sustainable products (usually sustainable products are more expensive than traditional one) (Diamantopoulos, Schlegelmilchb, Sinkovicsd, \& Bohan, 2003; Vermier \& Verebeke, 2006; Young, Hwang, McDonald, \& Oats, 2010) (ii) distribution, the lack of product availability explains why some buyers tendencies remains low (Diamantopoulos, Schlegelmilchb, Sinkovicsd, \& Bohan, 2003; Vermier \& Verebeke, 2006; Thøgersen, 2010) (iii) lack of information on sustainable consumption behaviours (Ehrich \& Irwin, 2005; Von Meyer-Höfer, Wense, \& Spiller, 2013). (Vermier \& Verebeke, 2006) believes that consumer behaviour can be influenced by increasing the information. (iv) time available, usually consumers don't have enough time to undertake market research needed for sustainable products. They use to by traditional products that are familiar with (Young, Hwang, McDonald, \& Oats, 2010).

However, (Thøgersen, 2010) believes that consuming patterns differ from country to country. He emphasises the important role of structural factors (policy instruments, financial support, distribution systems) in promoting sustainable consumption.

The rest of this paper is structured as follows. Section 2 describes the methodology used. Section 3 submit the consequential results of the empirical research. Finally, our conclusions and recommendations are represented in section 4.

\section{METHODOLOGY}

The data were collected with the help of a close ended questionnaire. Likert scale questions are used to measure the attitude and behaviour of Albanian consumers 
toward sustainable consumption. The responses were collected on a 5-point Likert Scale.

Through the survey is collected information about the dependent variables: adapting SC behaviour and the independent variables: exploratory variables used to test the relationship that exists between depended and independent variables.

The data were collected through a self-administered questionnaire. Simple Random Sampling was used in this study for choosing respondents. 660 questionnaires were selected during 1-30 March 2016. The survey instrument was divided into three sections. $1^{\text {st }}$ Section: obtained demographic and psychographic information about the respondents, $2^{\text {nd }}$ section addressed the perceptions and attitudes of respondents about sustainability issues, $3^{\mathrm{d}}$ section measures the behaviour of the respondent toward sustainable consumption

Multiple regression method, Exploratory Factor Analysis, (EFA) and Principal Component Analysis (PCA) are used to exam relationship between the depended and independent variables.

PCA is a variable reduction technique which identifies the number of latent constructs and the underlying factors structure to a set of variables. PCA aims to identify a small number of derived variables from a larger number of original variables to simplify the consequent analysis of the data (Kootstra, 2004). The factor analysis model expresses the variation and co-variation in a set of observed continuous variables $\mathrm{X}$ as a function of $\mathrm{F}$ factors and residuals e for person. Through EFA we will estimate the factors which influence attitude and behaviour toward sustainable consumption. Factor analysis attempts to bring intercorrelated variables together (Tucker \& MacCallum, 1997) (Kootstra, 2004).

Several tests are used to control the relevance and reliability of data for factor analysis. Kaiser-Meyer-Olkin is used to measure the adequacy for each variable. KMO tests the ratio of item correlation to partial item correlation. The range of KMO is between 0.0 to 1.0 , the KMO should have a value over 0.5 for a good PCA. Bartlett's test of sphericity tests the validity and appropriateness of the answers collected through the questionnaires. Bartlett's test the hypothesis that the correlation matrix is an identify matrix (variables are uncorrelated). If the Bartlett's test of sphericity is statistically significant we reject the null hypothesis which means that there are correlations in the data set that are appropriate for PCA. Cronbach's alpha is used to measure the internal consistency of the data set. Cronbach's alpha is acceptable if it takes value above 0.7.

Regression analysis is used to investigate the relationship between the main factors obtained from the PCA.

\section{RESULTS}

Our sample is composed of 660 respondents, $61 \%$ female respondents and $39 \%$ male respondents. $46 \%$ of our respondents are less than 25 years old, $25 \%$ are between 25-34 years old, $14 \%$ are between $35-44$ years old and 14,5\% are more than 45 years old.

The main external factors that influence sustainable consumption behaviour are: income, infrastructure, product availability, and lack of information. $50 \%$ of the respondents were not satisfied from public transportation quality, $43 \%$ of them complain about the availability of cycling roads, $64 \%$ of the respondents emphasised that low income is the main reason for having unsustainable consumption patterns.

Multivariate analysis is used to identify the internal determinants that influence consumers behaviour toward SC. Principal Component Analysis is used to reduce the complex data set. PCA aim is to extract information by depended variables used to measure knowledge, attitude, and behaviour towards sustainable consumption and to 
represent this information as a set of new variables called principal components. Factors driven from PCA are used in regression analysis to test the hypothesis.

KMO, Cronbach's alpha, and Bartlett's test indicate that we can perform efficiently a principal component analysis on our dataset (table 1) Cronbach's alpha indicates that variables used for this study have a relatively high consistency, so the reliability of the scale is good for carrying out factor analysis for each index, respectively. KMO shows a very good sample for performing factor analysis. Bartlett's sphericity test is statistically significant $(\mathrm{a}=1 \%)$. This guarantees reliable results from factor analysis. From the data set five indexes are computed

Table 1. Kaiser-Meyer-Olkin, Bartlett's sphericity test and Cronbach's alpha

\begin{tabular}{llrrrrr}
\hline KMO the Bartlett's Test & $\begin{array}{c}\text { Personality } \\
\text { index }\end{array}$ & $\begin{array}{c}\text { Knowledge } \\
\text { index }\end{array}$ & $\begin{array}{c}\text { Attitude } \\
\text { index }\end{array}$ & $\begin{array}{c}\text { PCE } \\
\text { index }\end{array}$ & $\begin{array}{c}\text { Lifestyle } \\
\text { index }\end{array}$ \\
\hline $\begin{array}{l}\text { Kaiser-Meyer-Olkin Measure of Sampling } \\
\text { Adequacy }\end{array}$ & 0.872 & 0.893 & 0.89 & 0.872 & 0.816 \\
\hline Bartlett's Test of & Approx. Chi-Square & 2688.838 & 2407.615 & 2113.54 & 2076.9 & 1341.692 \\
Sphericity & df & 136 & 45 & 21 & 21 & 66 \\
& Sig. & 0 & 0 & 0 & 0 & 0 \\
\hline & \multicolumn{7}{c}{ Realibility statistics } \\
\hline Cronbach's Alpha & 0.875 & 0.867 & 0.88 & 0.875 & 0.762 \\
Number of items & 17 & 10 & 7 & 7 & 16 \\
\hline
\end{tabular}

Personality index is related to variables that measures personality traits. This factor includes 17 of the original variables. Knowledge index is linked to variables that measure consumer knowledge towards sustainable development. This factor includes 10 of the original variables. Attitude index is associated with variables that measures consumer attitude towards sustainability issues. This factor contains 7 of the original variables. $P C E$ index is linked to variables that measures consumers perceived effectiveness towards sustainable development. This factor contains 7 of the original variables. Lifestyle index is linked to variables that measure lifestyle activities. This factor includes 16 of the original variables.

\section{Index of carrying out activities related to sustainable consumption}

In order to analyse the frequency of carrying out activities related to sustainable consumption in addition to a common index of sustainable behaviour other more detailed/focused indexes were created. Common index include 16 variables that indicate behaviours related to sustainable consumption. Results are represented in the table 2 . Cronbach's alpha indicates good internal consistency (0.747). KMO indicates that the degree of common variance among sixteen variables is meritorious ( $\mathrm{KMO}=0.818$ ). Bartlett's sphericity test is statistically significant. The elements of the diagonal matrix vary $0.695-0.877$. Therefore, factor analysis could be applied to reduce the number of factors. Subtracted component of sustainable consumption behaviour explains 26.919 percent of the variation of the 16 original variables

Table 2. Kaiser-Meyer-Olkin, Bartlett's sphericity test and Cronbach's alpha for index of SC Activities

\begin{tabular}{llr}
\hline KMO and Bartlett's Test & \\
\hline \multicolumn{2}{l}{ Kaiser-Meyer-Olkin Measure of Sampling Adequacy. } & .818 \\
\hline Bartlett's Test of Sphericity & Approx. Chi-Square & 1688.539 \\
& Df & 91 \\
& Sig. & 0.000 \\
\hline Reliability Statistics & & \\
\hline Cronbach's Alpha & N of Items & \\
\hline .747 & 14 & \\
\hline
\end{tabular}


In subtracting, detailed indexes are used 16 original variables. Two criteria are used for selecting specified indexes: first, the eigenvalue associated with a component is more than 1. Second, a component should have at least two variables in his composition. Based on these criteria no variables were excluded from the analysis. The rotation used to better interpret the factors derived from the analysis is Varimax. The Varimax rotation indicates 4 principal components with eigenvalues greater than one.

Four components result from the analysis: $1^{\text {st }}$ Component named "energy" is related to variables that measures behaviours related with energy consuming patterns. These variables measure the frequency of carrying out activities that tend to reduce energy consumption like: switch off lights when not at home, save water, choosing energy efficient gadgets, washing clothes at lower temperatures. This factor explains 16.5 percent of the variation of the original variables. $2^{\text {nd }}$ Component named "products" is strongly related to other variables, more explicitly frequency of adopting behaviour related to sustainable products such as: buying locally produced products, consuming seasonal products; buying biological products when available, using recyclable products; using product with low environmental impact. This factor explains 15.834 percent of the variation of the original variables. $3^{\mathrm{d}}$ component named "awareness" is includes three original variables that are strongly related with awareness towards sustainable consumption: use of public transportation even though you might own a private car, use of bicycle, switch off the gadgets when not at home, recycle habits. This factor explains 12.636 percent of the variation of the original variables. $4^{\text {th }}$ Component of the analyses named "Transportation" is related strongly with 2 variables that are strongly related with sustainable transport behaviour. Using of public transportation and walking. Consumers that carry out these activates more frequently seem to adopt green transportation behaviour This factor explains 11.186 percent of the variation of the original variables.

These 4 components correspond to an overall cumulative variance of 56.155 percent of the variation of the original variables. These components are used in the following section to investigate the connection between sustainable consumption behaviour and personality traits, concern about sustainability, knowledge importance and lifestyle.

Table 3 represents the variables included in analysis and their correlation with four components resulting from factor analysis.

Table 3. Variables included in analysis and their correlation with four components resulting from factor analysis

\begin{tabular}{lrrrr}
\hline \multirow{2}{*}{ Variables } & \multicolumn{4}{c}{ Index } \\
\cline { 2 - 5 } & 1 & 2 & 3 & 4 \\
\hline Use of public transportation & -.047 & .126 & .022 & $\mathbf{. 7 3 8}$ \\
Use of public transportation even though you might own a private car & .076 & .130 & $\mathbf{. 4 9 3}$ & .462 \\
Walking & .293 & .083 & .041 & $\mathbf{. 6 5 4}$ \\
Cycling & -.012 & .120 & $\mathbf{. 7 0 4}$ & .200 \\
Buy local produced products, seasonal products & -.037 & $\mathbf{. 6 3 0}$ & -.079 & .323 \\
Buy biological products when available & .133 & $\mathbf{. 7 1 7}$ & -.168 & .286 \\
Use recyclable products & .228 & $\mathbf{. 7 1 8}$ & .305 & -.062 \\
Use products with low environmental impact & .346 & $\mathbf{. 6 7 9}$ & .254 & -.034 \\
Switch off lights when not at home & $\mathbf{. 5 7 1}$ & .116 & -.367 & .332 \\
Wash clothes at lower temperatures & $\mathbf{. 6 4 4}$ & .143 & .267 & -.039 \\
Recycle & .419 & .362 & $\mathbf{. 5 2 4}$ & -.063 \\
Save water & $\mathbf{. 8 0 7}$ & .004 & -.002 & .149 \\
Choosing energy efficient gadgets & $\mathbf{. 6 7 7}$ & .322 & -.007 & .048 \\
Switch off gadgets when not using them & -.003 & .081 & $\mathbf{. . 5 9 7}$ & .088 \\
\hline
\end{tabular}




\section{Multiple regression}

In this section multiple regressions are being conducted to identify the main determinants that influence sustainable consumption. Exploratory variables include demographic variables, personality traits index, knowledge index, consumers precieved efectivenes index, lifestyle index.

First multiple regression is computed using all the exploratory variables. The calculation procedure was repeated afterwards excluding the statistically insignificant variables. Fisher test $F(10,551)=0.66$, Prob $>F=0.7600$ for these variables indicate that these variables are statistically non-significant and can be omitted from the regression. The results of the re-evaluated and re-diagnosed regression are presented in table 4 The result of the regression was finally inspected to ensure that there was no homoscedasticity among the predictor variables. The functional form test and the homoscedasticity test have provided the appropriate results. All variables are statistically significant in confidence level 5\%, except civil status.

Table 4 Determinants of sustainable consumption

\begin{tabular}{|c|c|c|c|c|c|c|}
\hline Activities all & Coef. & Std. Err. & $\mathbf{t}$ & $P>t$ & \multicolumn{2}{|c|}{ [95\% Conf. Interval] } \\
\hline Education/MSc, $\mathrm{PhD}$ & -0.220 & 0.103 & -2.140 & 0.033 & -0.421 & -0.018 \\
\hline Civil status: Married & 0.122 & 0.079 & 1.540 & 0.124 & -0.034 & 0.278 \\
\hline Personality traits & 0.110 & 0.043 & 2.530 & 0.012 & 0.025 & 0.195 \\
\hline Knowledge & 0.131 & 0.043 & 3.060 & 0.002 & 0.047 & 0.215 \\
\hline PCE & 0.204 & 0.040 & 5.150 & 0.000 & 0.126 & 0.282 \\
\hline Life style & 0.328 & 0.040 & 8.160 & 0.000 & 0.249 & 0.407 \\
\hline _cons & -0.010 & 0.044 & -0.240 & 0.813 & -0.096 & 0.075 \\
\hline$N=569$ & & \multicolumn{2}{|c|}{ R-squared $=0.308$} & \multicolumn{3}{|c|}{ Adj R-squared = 0.301} \\
\hline & \multicolumn{2}{|c|}{ RESET test: $F(3,559)=$} & \multicolumn{3}{|c|}{ Prob $>$ F $=0.227$} & \\
\hline \multicolumn{7}{|c|}{ Breusch-Pagan / Cook-Weisberg test for homoscedasticity: } \\
\hline
\end{tabular}

All variables (except education) have the predictable sign. Which indicates that Personality characteristics, knowledge, PCE, Lifestyle and civil status are positively related to sustainable consumption. Informed consumers, consumer with high consumer perceived effectiveness, are more likely to adopt sustainable consumption behaviour. Also, liberal, original, innovative, collaborative persons are more likely to adopt sustainable consumption behaviour. Lifestyle is likewise strongly related to sustainable consumption, active people, people worried about their health, activists of civil society are more likely to adopt sustainable consumer behaviour. The only variable that is inconsistent with the theory is education. According to regression coefficients educated people that have a post university degree are less likely to adopt sustainable consumption behaviour.

Multiple regression is computed for every detailed component of sustainable consumption (Table 5). The functional forms for the four regressions are well-specified at the 5 percent level. 
Table 5. The determinants of energy index, products index, awareness index, transportation index

\begin{tabular}{|c|c|c|c|c|}
\hline Variable & $\begin{array}{c}\text { Energy } \\
\text { index }\end{array}$ & $\begin{array}{c}\text { Products } \\
\text { index }\end{array}$ & $\begin{array}{c}\text { Awareness } \\
\text { index }\end{array}$ & $\begin{array}{c}\text { Transport } \\
\text { Index }\end{array}$ \\
\hline Gender & -0.02 & -0.009 & $0.168^{* *}$ & -0.048 \\
\hline age18_24 & 0.041 & 0.011 & 0.047 & 0.048 \\
\hline age25_34 & 0.035 & 0.099 & 0.113 & -0.233 \\
\hline age35_44 & -0.078 & -0.08 & 0.151 & $-0.356 * *$ \\
\hline Education: University degree & -0.06 & 0.091 & $0.184 *$ & -0.047 \\
\hline Education: MSc, $\mathrm{PhD}$ degree & -0.225 & -0.026 & $0.314 * *$ & -0.03 \\
\hline income22_40K AL & 0.024 & -0.051 & 0.046 & -0.11 \\
\hline income40_90KALL & -0.024 & 0.138 & -0.121 & -0.032 \\
\hline Civil status: Married & 0.188 & $0.271 * *$ & -0.055 & $-0.242 * *$ \\
\hline employed & 0.104 & -0.19 & -0.047 & 0.035 \\
\hline student & -0.059 & -0.099 & -0.118 & 0.151 \\
\hline personality index & $0.108 * *$ & 0.066 & $0.217 * * *$ & $0.173 * * *$ \\
\hline Knowledge Index & $0.087 *$ & 0.057 & 0.036 & 0.044 \\
\hline awareness index & $0.170^{* * * *}$ & 0.031 & $0.118 * *$ & $-0.103 * *$ \\
\hline PCE & $0.080 *$ & $0.128 * * *$ & $0.084 *$ & $0.096 * *$ \\
\hline life style & 0.027 & $0.259 * * *$ & $0.524 * * *$ & -0.011 \\
\hline _cons & -0.045 & -0.044 & 0.122 & 0.196 \\
\hline $\mathrm{N}$ & 568 & 568 & 568 & 568 \\
\hline $\mathrm{R}^{2}$ & 0.124 & 0.167 & 0.258 & 0.11 \\
\hline $\mathrm{R}^{2}$-adj & 0.099 & 0.143 & 0.236 & 0.084 \\
\hline RESET & 0.227 & 0.067 & 0.241 & 0.065 \\
\hline
\end{tabular}

legend: $* p<.1 ; * * p<.05 ; * * * p<.01$

The set of all statistically insignificant variables is removed from every regression. The regressions of the detailed factors of sustainable consumption have been diagnosed and re-evaluated.

As is shown in table 6 the energy saving behaviour is determined from the personality index (significant 5\% level), awareness index (significant $1 \%$ level), perceived consumer effectiveness (significant $10 \%$ level). All variables have the expected positive sign. Multiple regression of the energy index indicates that sustainable consumption related to energy consumption is influenced from PCE, personality and awareness.

Table 6. Reduced model for determinants of energy-saving behavior with robust errors for heteroskedasticity

\begin{tabular}{lcccccc}
\hline Energy index & Coef. & Robust std. err. & $\mathbf{t}$ & $\mathbf{P}>|\mathbf{t}|$ & [95\% Conf. interval] \\
\hline personality index & 0.116 & 0.048 & 2.430 & 0.015 & 0.022 & 0.211 \\
knowledge & 0.086 & 0.053 & 1.630 & 0.104 & -0.018 & 0.189 \\
awareness index & 0.152 & 0.049 & 3.110 & 0.002 & 0.056 & 0.247 \\
PCE & 0.080 & 0.048 & 1.710 & 0.098 & -0.015 & 0.175 \\
_cons & -0.011 & 0.040 & -0.280 & 0.781 & -0.090 & 0.067 \\
\hline $\mathbf{N = 5 6 9}$ & \multicolumn{3}{c}{ Root MSE $=\mathbf{0 . 9 4 6 2 9}$} \\
\hline
\end{tabular}

Table 7 shows a reduced model for factor that influence buying sustainable products. All the variables in regression are statistically significant and have the expected positive sign. The results indicate that married people, consumers with high 
perceived e effectiveness are more likely to buy sustainable products. Lifestyle is also related with behaviour towards sustainable products.

Table 7. Reduced model for determinants of buying sustainable product with robust errors for heteroskedasticity

\begin{tabular}{|c|c|c|c|c|c|c|}
\hline Product Index & Coef. & Robust std. err. & $\mathbf{t}$ & $\mathbf{P}>|\mathbf{t}|$ & \multicolumn{2}{|c|}{ [95\% Conf. interval] } \\
\hline Civil status: Married & 0.196 & 0.091 & 2.160 & 0.031 & 0.018 & 0.374 \\
\hline PCE & 0.19 & 0.043 & 4.520 & 0.000 & 0.110 & 0.279 \\
\hline life style & 0.299 & 0.040 & 7.470 & 0.000 & 0.220 & 0.377 \\
\hline _cons & -0.054 & 0.045 & -1.190 & 0.234 & -0.142 & 0.035 \\
\hline \multirow[t]{2}{*}{$N=575$} & \multicolumn{3}{|c|}{ R-squared = 0.1096 } & \multicolumn{3}{|c|}{ Root MSE $=\mathbf{0 . 9 2 7 5 8}$} \\
\hline & F $(3,57$ & 34.13 & $\mathrm{~b}>\mathrm{F}=$ & 0.000 & & \\
\hline
\end{tabular}

The reduced model for awareness index have not the right functional form ( $\mathrm{F}(3$, $558)=3.08$, Prob $>F=0.0272$ ) which means that statistically non-significant variables should not be excluded from the multiple regression. Results presented in table 5 indicates that gender (statistically significant 5\% level) is the determinant factor of awareness index towards sustainable consumption. Education is also a significant factor that influence sustainable consumption behaviour. Educated people that hold a university or post university degree are more likely to adopt sustainable consumption behaviour related with awareness towards sustainability. Personality characteristic, perceived consumers effectiveness, lifestyle have an important positive relationship with awareness index.

Finally, reduced model for transport index is estimated. All non-significant variables are dropped from the model. The results are represented in table 8 All the variables are statistically significant at 5\% confidence level. Young people between 25 44 years old are less likely to adopt sustainable transport behaviour. Also married people are less likely to use sustainable transport means. Personality characteristics and perceived consumer effectiveness are positively related to sustainable transport index.

Table 8. Reduced model for determinants of the transport index with robust errors for heteroskedasticity

\begin{tabular}{|c|c|c|c|c|c|c|}
\hline Transport & Coef. & Robust std. err. & $\mathbf{t}$ & $\mathbf{P}>|\mathbf{t}|$ & \multicolumn{2}{|c|}{ [95\% Conf. Interval] } \\
\hline age35_44 & -0.287 & 0.125 & -2.300 & 0.022 & -0.533 & -0.042 \\
\hline Civil status: Married & -0.32 & 0.096 & -3.290 & 0.001 & -0.507 & -0.128 \\
\hline personality index & 0.172 & 0.045 & 3.830 & 0.000 & 0.084 & 0.260 \\
\hline awareness index & -0.081 & 0.047 & -1.710 & 0.087 & -0.174 & 0.012 \\
\hline PCE & 0.094 & 0.047 & 2.010 & 0.045 & 0.002 & 0.186 \\
\hline _cons & 0.132 & 0.049 & 2.720 & 0.007 & 0.037 & 0.227 \\
\hline \multirow[t]{2}{*}{$N=570$} & & \multicolumn{2}{|c|}{ R-squared = 0.0837} & \multicolumn{3}{|c|}{ Root MSE $=0.96364$} \\
\hline & $\mathrm{F}(\mathbf{5}, 5$ & 10.30 & $\operatorname{Prob}>\mathbf{F}=$ & 0.000 & & \\
\hline
\end{tabular}

\section{CONCLUSIONS AND RECOMMENDATIONS}

Sustainable consumer behaviours are seen only in a small number of Albanian consumers. Sustainable consumption behaviour in Albania is influenced from internal and external determinants. The main factors that influence behaviour towards sustainability are as follows: External factors Additional cost, generally sustainable products more expensive than traditional one. However, only $30 \%$ of the respondents 
have expressed their willingness to pay an extra price for buying sustainable products. Lack of information towards sustainable behaviours in general and towards sustainable products specifically. $61 \%$ of the respondents admit that they have insufficient or no information about sustainable products or sustainable behaviour. Inefficient distribution of sustainable products is another factor that influences consumer behaviour. $54 \%$ of the respondent's support that usually they must make extra efforts to find sustainable products. Infrastructure have a significant role in decision-making regarding mobility. Usually, consumers prefer less sustainable mobility patterns (e.g. private cars) because there are no sustainable alternatives (e.g. bike paths) or because of the low performance of sustainable alternatives (e.g. public transportation). Income level has a significant influence on consumers decisions regarding sustainable consumption. $64 \%$ of the respondents acknowledge that one of the main barriers in adapting sustainable consuming behaviours is inadequate income.

The main internal factor that influence consumer behaviour are: personality traits, original persons, collaborative, innovator individuals are more likely to adapt sustainable consuming behaviour; Knowledge is strongly related to sustainable consumption. An individual that has sufficient knowledge according sustainability issues is more inclined to sustainable consumption; Perceived consumers effectiveness is positively related to sustainable consumption. Individuals who believe that their individual behaviour will have an impact in issues related to sustainability are more likely to adapt sustainable consumption patterns. Lifestyle is positively related with SC. Individuals that have an active lifestyle, individuals with high social engagement, individuals involved in the decision-making process, are more likely to adopt SC. Also, individuals that follow a healthy lifestyle are more likely to adopt SC. On the other hand, demographic variables have a small influence in behaviour related to sustainable consumption. Only two demographic variables are statistically significant civil status and education.

However, further analysis indicated that the influence of internal determinants is different for detailed factors of sustainable consumption. More explicitly:

The main factor that influence sustainable consumption behaviour related to energy consumption are: personality characteristics, attitude towards sustainability and perceived consumers effectiveness. Sustainable behaviour related with consuming sustainable products is influenced mostly by civil status of individuals, perceived consumers effectiveness and lifestyle.

Sustainable consumption related with mobility is influenced by demographic variables (civil status, age,) personality characteristics and perceived consumers effectiveness.

\section{REFERENCES}

UNEP. (2012). Measuring progress: environmental goals \& gaps. Nairobi: United

Nations Environment Programme. Gjetur në

http://www.unep.org/geo/pdfs/geo5/ Measuring_progress.pdf

Anastasiadis, \& Dam, v. (2014). Consumer driven supply chains: the case of Dutch organic tomato. Agric Eng Int:CIGR Journal, Special issue 2014: Agri-food and biomass supply chains, $11-20$.

Assadourian, E. (2010). Cultural change for a bearable climate. Sustainability: Science, Practice, \& Policy 6(2), Sustainability: Science, Practice, \& Policy 6(2).

Baumol, W., \& Oates, W. (1998). The Theory of Environmental Policy. New York: Cambrige University Press. 
Blend, J., \& van Ravenswaay, E. O. (1999). Consumer Demand for Eco-labeled Apples: Results from Econometric Estimation. American Journal Agriculture Economics, 81, 1072-1077.

Boulanger, P.-M. (2010, September 09). Three strategies for sustainable consumption. S.A.P.I.EN.S. Gjetur October 11, 2012, nga URL : http://sapiens.revues.org/1022

Brunsø, K., \& Grunert, K. G. (1995). Development and testing of a cross-culturally valid instrument: Food-related lifestyle. Advancesin Consumer Research, 22, 475-480.

Chen, J., Lobo, A., \& Rajendran, N. (2014). Drivers of organic food purchase intentions in mainland China evaluating potential customers attitudes, demographics and segmentation. International Journal of Consumer Studies Vol. 38, Issue 4, 346356.

Diamandopoulos, A. (2003). Can socio-demographic still play a role in profiling green consumers? A review of the evidence and an empirical investigation. Journal of Business Research, 465-480.

Diamantopoulos, A., Schlegelmilchb, B. b., Sinkovicsd, R. R., \& Bohan, G. M. (2003). Can socio-demographics still play a role in profiling green consumers? A review of the evidence and an empirical investigation. Journal of Business Research 56, 465-480.

ECEU. (2011).fq. 4 Buying green! A handbook on green public procurement (bot. i 2nd Edition). http://ec.europa.eu/environment/gpp/pdf/handbook.pdf: European Commision European Union.

Ehrich, K., \& Irwin, J. (2005). Will ful Ignorance in the Request for Product Attribute Information. Journal of Marketing Research, 42 (August), 266-277.

Field, A. (2000). Discovering Statistics using SPSS for Windows. (bot. i 2). London Thousand Oaks -New Delhi: Sage publications.

Jackson, T. (2005). Motivating Sustainable Consumption: a review of evidence on consumer behaviour and behavioural change. London: London: Policy Studies.

Kootstra, G. J. (2004). Exploratory Factor Analysis: Theorz and application. Gjetur June 10, 2016, nga http://www.let.rug.nl/nerbonne/teach/rema-ststs-methseminar/Factor-Analysis-Kootstra-04.PDF

Kothari, C. R. (2004). Research Methodology, Methods and techniques. New Age International (P) Ltd., Publishers.

Lorek, S., \& Fuchs, D. (2011). Strong sustainable consumption governance e precondition for a degrowth path? Journal of Cleaner Production. doi:doi:10.1016/j.jclepro.2011.08.008

Luchs, M. G., Naylor, R. W., Irwin, J. R., \& Raghunathan, R. (2010). TheSustainability Liability: Potential Negative Effects of Ethicality on Product Preference. Journal of Marketing, 74 (5), 18-31.

Papaoikonomou, E., Valverde, M., \& Ryan, G. (2012). Articulating the Meanings of Collective Experiences of Ethical Consumption. Journal of Business Ethics, $110(1), 15-32$.

Pezzini, G. (2013). Ethical consumption and Iceland A review of current literature and an exploratory study. Prentun: Háskólaprent.

Power, K., \& Mont, O. (2010). The Role of Formal and Informal Forces in Shaping Consumption and Implications for Sustainable Society: Part II. sustainability, 2, 2573-2592. 
Salonen, A. O., Fredriksson, L., Järvinen, S., Korteniemi, P., \& Danielsson, J. (2014). Sustainable Consumption in Finland-The Phenomenon, Consumer Profiles, and Future Scenarios. International Journal of Marketing Studies, 6(4), 59-82.

Spaagaren, G. (2003). Sustainable Consumption: ATheoretical and Environmental Policy Perspective. Society and Natural Resources , 16, 687-701.

Spaargaren, G., \& Oosterveer, P. (2010). Citizen-Consumers as Agents of Change in Globalizing Modernity: The Case of Sustainable Consumption. Sustainability, 2, 1887-1908.

Straughan, R. D., \& Roberts, J. A. (1999). Environmental segmentation alternatives: a look at green consumer behavior in the new millennium. Journal of Consumer Marketing, 16(6), 558-575.

Thøgersen, J. (2010). Country Differences in Sustainable Consumption: The Case of Organic Food. Journal of Macromarketing 30(2) , 171-185.

Tucker, L. R., \& MacCallum, R. C. (1997). Exploratorz Factor Analysis. Univeristy of Illinois.

UN. (2012). The UN System Task Team on Post-2015. Realizing the future we want for all. UN System Task Team on the Post- 2015 UN Development Agenda. New York: United Nations. Gjetur në http://www.un.org/millenniumgoals/pdf/Post_2015_UNTTreport.pdf

UN. (2015). The Millennium Development Goals Report. United Nations . Gjetur në http://www.undp.org/content/dam/undp/library/MDG/english/UNDP_MDG_R eport_2015.pdf

UNEP. (2002). Report of the World Summit on Sustainable Development. Johanesburg, South Africa: UNEP.

Verain, M. C., Bartels, J., Dagevos, H., Sijtsema, S. J., Onwezen, M. C., \& Antonides, G. (2012). Segments of sustainable food consumers:a literature review. International Journal of Consumer Studies ISSN 1470-6423, 36, 123-132.

Vermier, I., \& Verebeke, W. (2006). Sustainable Food Consumption: Exploring the Consumer "Attitude - Behavioral Intention" Gap. Journal of Agricultural and Environmental Ethics, 19(2), 169-194.

Von Meyer-Höfer, M., Wense, V. v., \& Spiller, A. (2013). Characterising convinced sustainable food consumers. GlobalFood Discussion Papers No.28.

WBCSD. (a.d.). Sustainable Consumption Facts and Trends . The bussines Council for Sustainable Develeopment, http://www.wbcsd.org/pages/edocument/edocumentdetails.aspx?id=142.

Young, W., Hwang, K., McDonald, S., \& Oats, C. (2010). Sustainable consumption: green consumer behaviour when purchasing products. 20-31: Sustainable Development Journal 18. doi:DOI: 10.1002/sd

Zoysa, U. (2011). Millennium consumption goals: a fair proposal from the poor to the rich. Sustainability: Science, Practice, \& Policy , 7(1). Gjetur në http://sspp.proquest.com 